\title{
Ірина МАТЯШ,
}

доктор історичних наук, професор, провідний науковий співробітник відділу історії міжнародних відносин та зовнішньої політики України Інституту історії

України НАН України, голова правління Наукового товариства історії дипломатії та міжнародних відносин

\section{ПЕРШІ БІЛОРУСЬКІ ПРЕДСТАВНИЦТВА В УКРАЇНI (1918 p.): спроба встановлення дипломатичних відносин між УНР і БНР (романтика сподівань і реалії буття)}

Анотація. У статті висвітлено спроби встановлення офіційних міждержавних відносин між Білоруською Народною Республікою і Українською Народною Республікою у 1917-1920рр. На основі архівної інформації з фондів українських та білоруських архівних установ висвітлено діяльність білоруських представництв в УНР і Українській Державі. Проаналізовано позиції білоруських представників у переговорному процесі з українською стороною. Значну увагу приділено персоналіям представників БНР, з'ясовано маловідомі факти їхнього життєвого шляху.

Ключові слова: персоналії, Білоруська торгова палата БНР, білоруські представництва в Україні, П. Алексюк, П. Тремпович, О. Цвікевич, М. Довнар-Запольський.

В історії української дипломатії 2018 рік має особливе значення. Він знаменує собою століття виходу України на міжнародну арену як незалежної держави і встановлення офіційних відносин із зарубіжними країнами. Як наголошував перший міністр закордонних справ УНР Олександр Шульгин, «блискучий розвиток нашої державности, який на певний час зробив Україну “оазісом" серед всеросійського безладдя, звернув на себе загальну увагу. До Києва стали наїздити делегації від різних частин колишньої імперії царів і з захопленням дивитись на ту організаційну роботу, яка перейнята була всенароднім ентузіазмом. Дивитись і потім робити спроби досягти того ж й у своїх країнах» [1]. До таких країн належала, зокрема, Білорусь. 
У білоруській, польській, українській історіографії достатньо уваги приділено питанню створення Білоруської Народної Республіки, особам ії репрезентантів та спробам зберегти білоруську державність. Окремий напрямок досліджень у цьому контексті складають дослідження процесу встановлення двосторонніх відносин УНР і БНР (О. Кукса [2], В. Лєбєдєва [3, 4], М. Трус [5] (Республіка Білорусь), В. Матвієнко [7-9], О. Зубко [5, 6], I. I. Матяш [10-11], О. Панасюк [12] (Україна), Д. Міхалюк [13-14] (Республіка Польща) та ін.). Актуальність звернення до питання діяльності перших білоруських преставництв в Україні зумовлена потребою реконструції процесу встановлення двосторонніх відносин між УНР і БНР та його інституційних форм у 1917-1920 рр. як доказу столітньої історії офіційних українсько-білоруських взаємин, а також - з'ясування формальних аспектів взаємного визнання держав. Своїм завданням у цій статті вважаємо аналіз інституційних форм встановлення дипломатичних відносин між Білоруською Народною Республікою і УНР / Українською Державою та їх репрезентантів в українській столиці (абстрагуючись від діяльності консульства БНР в Одесі).

Серед новоутворених держав, що постали на руїнах Російської імперії, Білорусь робила найактивніші кроки до встановлення офіційних двосторонніх відносин з УНР. Причиною тому була потреба молодої держави в дієвій підтримці ззовні, особливо з боку сусідів. Ще за три місяці до проголошення Білоруської Народної Республіки «рідну сестру» вітала оплесками на своєму засіданні 17 грудня 1917 року Українська Центральна Рада [15, с. 35]. Про очікуване проголошення самостійності Білорусі сповістив делегат Білоруського військового з'їзду, що відбувався тоді в Києві. Перші білорусько-українські контакти «міждержавного» рівня були пов'язані з формуванням складу делегації на Брестські мирні переговори. Виконавчий комітет Ради Першого Всебілоруського з'їзду, розігнаного 18 грудня 1917 року «озброєною бандою більшовицької влади», в особах його голови Іосифа Воронка і секретаря Александра Бурбіса, звернувся до Генерального Секретаріату УЦР з проханням покласти на українських делегатів на Брестських мирних переговорах відповідно до ноти Генерального Секретаріату УЦР захист прав Білорусі до приїзду в БрестЛитовськ білоруських представників [16, арк. 48]. Виконком діяв у підпіллі, практично без матеріальних засобів, маючи доручення взяти владу в свої руки тоді, коли це буде можливо, й намагаючись реалізувати резолюції, що їх не вдалося прийняти в демократичний спосіб [17, с. 553]. Як відомо, з'їзд устиг офіційно ухвалити лише перший параграф постанови, який передбачав реалізацію білоруським народом права на самовизначення і створення органу крайової влади. Функціонуючи на нелегальних засадах, виконком як міг підтримував ідею білоруської влади, навіть вступаючи в контакт із іншими державними утвореннями. 
Вести всі переговори з українською стороною у разі прийняття нею звернення доручалося члену виконкому Білоруської центральної військової ради Павлу Алексюку [16, арк. 53]. Той без зволікань в останній декаді грудня 1917 року виїхав до Києва. «Посол» був активним учасником громадсько-політичної боротьби білорусів за незалежність. Він співпрацював із Мінським білоруським комітетом, як його представник увійшов до складу Виконавчого комітету громадської безпеки Мінська. Завдання цього комітету полягало в скасуванні разом із комендантом міста старої адміністрації та встановлення нового порядку [18]. Деякий час П. Алексюк був помічником голови Білоруського національного комітету Романа Скірмунта, сформованого 26 березня 1917 року на базі Мінського білоруського комітету. Цей орган фактично об'єднав зусилля всіх білоруських організацій, декларуючи національно-культурне і політичне відродження Білорусі, проте на засадах автономії у складі Росії. Подібні ідеї (зокрема, надання Білорусі національно-територіальної автономії у складі РСФРР та створення законодавчого органу - Білоруської крайової ради) містила програма створеної у травні 1917 року Білоруської партії народних соціалістів (члени: I. Сушинський, О. Левицький, С. Плавець та ін.). За характеристикою М. Довнара-Запольського, очолювана П. Алексюком партія відіграла «доволі помітну роль у білоруській справі» $[17$, с. 538]. Попри розбіжності щодо розуміння державного статусу Білорусі (автономія/самостійність) та суперечності всередині білоруського національного руху, П. Алексюк входив до складу його керівних органів, зокрема й до створеного в жовтні 1917 року нового крайового органу - Великої Білоруської Ради, покликаної «захищати весь білоруський народ» [19, с. 201]. Після насильного завершення I Всебілоруського з’їзу він отримав повноваження на ведення переговорів з Українською Центральною Радою як посол від виконкому з їзду.

Білоруському представникові, попри нелегальний статус виконкому, було надано відповідні повноваження. Його контакти з керівництвом, зокрема з комісаром Румунського фронту Павлом Манцевичем, здійснювалися через посередництво Секретарства з міжнаціональних, а з 22 грудня / 4 січня - міжнародних справ з використанням радіотелеграфного зв'язку. Скерована до Брест-Литовська білоруська делегація взяти дієвої участі в переговорах, як відомо, не змогла. До ії складу входили не випадкові особи: О. Цвікевич і С. Рак-Михайловський.

Олександр Іванович Цвікевич (1888-1937), уродженець Бреста і випускник юридичного факультету Санкт-Петербурзького університету (1912), попри 30-річний вік, мав високий авторитет серед білоруської спільноти і досвід громадсько-політичної діяльності: був учасником створення Білоруської народної громади в Москві, доповідачем з питань біженців на I Bсебілоруському з'їді [20]. 
Не менш яскравою особистістю був Симон Михайлович Рак-Михайловський (1885-1938) [21], педагог за освітою (закінчив 1912 року учительський інститут у Феодосії й працював учителем у чотирикласному вищому початковому училищі та жіночій гімназії в кримському містечку Карасубазар), голова Центральної білоруської військової ради, активний учасник I Всебілоруського з'їзду, член його президії і підпільного виконкому Ради з’їзду після його розгону.

Обидва делегати змогли потрапити в Брест-Литовськ лише як радники української делегації. «Делегація була в Бресті, - зазначав М. ДовнарЗапольський, - хоч офіційного значення мати не могла» [17, с. 553]. На час їх прибуття учасники переговорів отримали надіслану 19 січня 1918 року Виконкомом Ради Першого Всебілоруського з'їзду «Декларацію білоруської мирної делегації», в якій вказувалося, що Білорусь була у своїх етнографічних межах автономною частиною Російської федерації, тому вимагали возз'єднання етнічних частин Білорусі, розділених лінією фронту. Мета цього послання полягала в тому, щоб привернути увагу до проблеми білоруської державності, яка під час переговорів ігнорувалася. Проте ні декларація, ні делегати, що прибули до місця проведення переговорів із запізненням, впливу на перебіг переговорного процесу і зміст договору не мали. Договори, підписані представниками Української Народної Республіки 27 січня (9 лютого) 1918 року та Радянської Росії 3 березня 1918 року із Почвірним Союзом, не лише передбачали відторгнення частини білоруської території, а й заперечували іiі претензії на самостійність, визнаючи білоруські землі областями Радянської Росії, тимчасово окупованими німецькими військами. Ухвалене без урахування позиції білоруського уряду рішення, що порушувало національні й територіальні права Білорусі та її народу, білоруська сторона визнати відмовилася. Досягнення його перегляду білоруським лідерам вбачалося через сприяння УНР.

На початку квітня 1918 року О. Цвікевич та С. Рак-Михайловський вирушили до Києва вже як офіційні делегати Білоруської Народної Республіки (БНР), проголошеної 25 березня 1918 року згідно з III Статутною грамотою Ради Всебілоруського Конгресу. Відповідно до передбаченої у Брестському мирному договорі можливості проведення додаткових перемовин щодо уточнення лінії кордону (зокрема, російсько-українського) вони мали домовитися про встановлення кордонів БНР за етнографічним принципом й «повернути» віднесені договором до УНР південні повіти Гродненської і Мінської губерній. Згідно з III Статутною грамотою територія БНР окреслювалася в межах Могильовщини, Мінщини, Гродненщини (входили Гродно та Білосток), Віленщини, Вітебщини, Смоленщини і прикордонних частин сусідніх губерній, де проживали білоруси. Відтак офіційно білоруське представництво іменувалося «Делегація Народного 
Секретаріату БНР у справах переговорів із УНР», або «Надзвичайна делегація з міжнародних переговорів» [22, арк. 10]. Тим самим визначалася пріоритетна проблема, яка визнавалася БНР такою, що потребує негайного вирішення. Опис кордонів республіки спочатку належав до обов'язків комісії з міжнародних справ Ради БНР.

Крім того, очільник делегації О. Цвікевич мав виконати завдання політичного і економічного змісту. Вони полягали в офіційному повідомленні владі й народу Української Народної Республіки та всім державам (за допомогою українського радіотелеграфу) про проголошення незалежності БНР, веденні переговорів щодо визнання українською стороною нового статусу країни, налагодження телефонного та телеграфного зв'язку між Києвом і Мінськом, перегляду змісту Брестського мирного договору, а також в умовах відсутності білоруського консульського представника - створенні можливості для товарообміну між БНР і УНР та постійного сполучення між їх столицями, досягненні економічної підтримки грошовою позикою обсягом 500 тис. грн уряду БНР від УНР [23, с. 642] та сприяння в організації в Україні білоруських військових підрозділів. Щодо визнання незалежності йшлося про «офіційний акт, що став би основою для встановлення тіснішого державного зв’язку Білорусі й України», що надалі передбачало $б$ об’єднання автономних армій та єдність зовнішньої політики [22, арк. 642]. До повноважень О. Цвікевича як керівника представництва в економічній частині належала організація відкриття в Києві Білоруської торгової палати. Для реалізації надважливих для БНР завдань мав стати в нагоді його досвід юридичної практики в Пружанах і Брест-Литовську та робота в Комітеті допомоги жертвам війни (Тула, 1916).

На С. Рак-Михайловського покладалися обов'язки управління справами представництва БНР та секретаря. Його основне завдання в Києві полягало в організації білоруських військових частин на території УНР. Білоруські делегати розраховували на фінансову допомогу від української сторони, а також забезпечення зброєю, військовим спорядженням та продовольством як сформовані частини, так і ті, що мали формуватися [22, арк. 642].

Реалізації завдань делегації БНР повинна була сприяти білоруська періодика, що засновувалася в Києві. Перше видання «політичної, громадської, політико-економічної і військової» газети «Білоруське слово» вийшло 1 (19) квітня 1918 р. з програмною передовою статтею відомого вченого та амбітного організатора науки і освіти професора Митрофана Довнара-Запольського. Вчений народився у місті Речиця Мінської губернії, однак Київ був для нього не лише столицею Української Народної Республіки, в якої новопостала БНР шукала підтримки. Тут він навчався в 1-й Київській гімназії (звідки його було відраховано за неблагонадійність), 1894 року блискуче закінчив історико-філологічний факультет Київського 
університету Св. Володимира, формувався як учений-історик, захистивши дисертації: магістерську - «Государственное хозяйство Великого княжества Литовского при Ягеллонах» (1901р.) та докторську - «Очерки по организации западно-русского крестьянства в XVI в.». Також мав досвід створення вищого навчального закладу (Київський комерційний інститут, 1907 рік) та співпраці з різними громадськими організаціями, неодноразово обирався гласним Київської міської думи. Не були чужими для нього й українці: його наставник - видатний український історик В. Антонович, а дружина - український історик Н. Полонська-Василенко.

Лютий 1917 року закарбувався у пам'яті вченого захопленням влади лівореволюційним студентським комітетом в очолюваному ним Київському комерційному інституті, публічним зреченням його синами, які перейшли на бік більшовиків, та арештом, який завершився звільненням замість очікуваної страти [24, с. 296]. Після арешту він активно долучився до створення в Києві білоруських організацій. Закликаючи земляків до єднання в надзвичайно складний для громадян БНР час, М. Довнар-Запольський писав: «Українці, які багато настраждалися при Царському Уряді, не відмовлять білорусам у збереженні їхньої державності, якщо звісно ми самі будемо про це наполегливо заявляти» [25]. Важливими елементами боротьби він вважав запровадження білоруської мови в школі та державному управлінні, створення білоруського університету (пропонувався для цього Мозир) та народних університетів у провінційних містах, порушення питання про формування білоруського «передпарламенту» в українській столиці [25]. Публікацію «Уставної грамоти» в наступному числі газети від 8 (26 квітня) 1918 р. супроводжував заклик М.В. ДовнараЗапольського «сплотиться, напрячь все свои силы физические и культурные для того, чтобы оправдать наше право на самостоятельное существование и отстоять независимость нашей родины» [25]. Ця ідея стала основою для його програмної брошури «Основи державності Білорусі», відомої в історіографії як перша спроба наукового обгрунтування історичної закономірності самовизначення білоруського народу [26] й представленої в перекладі французькою мовою на Паризькій мирній конференції (18 січня - 29 червня 1919 року). У перших випусках «Білоруського слова» популяризувалося інше періодичне видання - газета «Белорусское эхо», забезпечення виходу якої покладалося на споряджену до Києва делегацію БНР.

Білоруські делегати розташувалася в будинку № 17 на вулиці Великій Васильківській [27, арк. 2]. Для потреб земляків член Білоруської організації на території України Степан Петрович Кебеца передав у користування власний автомобіль системи «Вазет» № 4370 [27, арк. 3]. Однак скоро після того служба штабу Головного коменданта м. Києва його реквізувала. 
Для повернення приватного транспорту, який опинився в гаражі штабу на Олександрівській вулиці, 3, О. Цвікевич звернувся до Народного міністерства закордонних справ УНР. «Прошу негайно написати до коменданта, просити повернути автомобіль або пояснити, через що він був реквізований», - дав вказівку відповідним службам Микола Любинський [27, арк. 2].

У квітні О. Цвікевич та С. Рак-Михайловський мали особисту зустріч із виконувачем обов'язків міністра закордонних справ УНР М. Любинським. А 5 квітня 1918 року їх прийняли голова Української Центральної Ради Михайло Грушевський та Міністр військових справ УНР Олександр Жуковський, а наступного дня - Міністр внутрішніх справ УНР Михайло Ткаченко [27, с. 85-86]. Водночас вони скерували до МЗС УНР ноту 3 запевненнями в почуттях «глибокої поваги та щирої братньої дружби» до «рідної України» та формулюванням проблеми щодо визначення кордонів Білорусі в її історично-етнографічних межах за участі білоруської делегації і надіслали тексти всіх трьох статутних грамот БНР [27, арк. 16-17]. Однак конкретних результатів із багатьох питань О. Цвікевичу спочатку отримати не вдалося.

У відповідь на ноту представників БНР Рада Народних Міністрів УНР 10 квітня 1918 року обговорила питання про визнання БНР незалежною державою, щодо якого не було одностайної думки (йшлося про компетенцію державних органів щодо офіційного визнання зарубіжної держави та потребу з'ясувати політичне становище БНР та ставлення інших держав до цього питання); про надання білоруській делегації доступу до радіотелеграфу, встановлення прямої лінії між Мінськом і Києвом та виділення грошової позики в розмірі 500000 карб. [15, с. 263]. Голова РНМ УНР і одночасно Міністр закордонних справ В. Голубович ознайомив присутніх також зі змістом переданих делегацією БНР уставних грамот Ради Білоруського з'їзду до народу Білорусі й запропонував проект повідомлення української сторони щодо визнання незалежності БНР. Проте зауваження Сергія Шелухина та Григорія Сидоренка вплинули на остаточне формулювання заяви РНМ УНР. Вони наголосили, що інформація про створення БНР стосується не лише української сторони, а й інших країн, а відтак $€$ потреба з'ясувати їхню позицію в цьому питанні. В обговоренні також йшлося про потребу вислати делегатів до Мінська для детального ознайомлення з цією справою (М. Ткаченко) та необхідність вивчити ставлення інших держав до визнання незалежності БНР (Г. Сидоренко). Тож питання про незалежність Білорусі з розгляду було знято, а МЗС УНР отримало доручення надати відповідь білоруській делегації.

Офіційна відповідь на ноту була достатньо обережною. Вона містила інформацію про те, що «Рада Народних Міністрів УНР принципово нічого не має проти визнання Білоруської Народної Республіки незалежною 
і буде втілювати цю справу в життя законним шляхом» [29, арк. 67-68]. Делікатність ситуації щодо офіційного визнання БНР, як зауважила білоруська дослідниця Валентина Лебедєва, зумовлювалася сформульованими в Брестському мирному договорі зобов'язаннями не визнавати «державних утворень на тимчасово окупованих територіях Росії, якою, згідно 3 формальним міжнародним статусом, була територія новопроголошеної БНР» [23, с. 643]. Залежність УНР від цих зобов'язань змушувала український уряд балансувати між бажанням допомогти братньому народові й позицією німецької адміністрації, яка набувала надзвичайних прав на українських теренах і не визнавала самостійності БНР. 3'ясувати ставлення Німеччини до визнання незалежності Білорусі отримав доручення посланник УНР у Берліні Олександр Севрюк, призначений для «тимчасового ведення всіх дипломатичних інтересів УНР» [30, с. 105]. Йшлося про отримання інформації («як німці дивляться на білоруську справу, і чи згодні вони визнати самостійну Білоруську Республіку» [30, с. 153]) не опосередковано через німецького посла барона Мумма, а безпосередньо з Берліна. Інформацію передбачалося використати також під час переговорів із Росією.

Однак початок розгляду питання щодо кордонів давав підстави говорити про формальне визнання українською стороною БНР. Для ведення переговорів із білоруською делегацією було створено комісію в складі членів Української Центральної Ради Анастаса Ліхнякевича, Мирона Петрівського, Миколи Свідерського з повноваженнями: «Скріпити особливим актом державні кордони між Україною та Білоруссю» [27, арк. 9]. О. Цвікевич розумів важливість підтримки знаними в Україні діячами білоруського походження (І. Красковським, М. Довнаром-Запольським) виконуваної делегацією місії, відтак залучав їх до активної співпраці. Одночасно зі створенням української комісії для ведення переговорів із БНР, очільник білоруської делегації, користуючись наданими йому Радою БНР повноваженнями, призначив консультантом делегації у справах переговорів з УНР із правом дорадчого голосу І. Красковського та М. Довнара-Запольського. В тій самій якості до роботи делегації долучився і керівник створеної у березні 1918 року Білоруської організації на території України I. Курилович. Планувалося, що висловлювані під час переговорів вимоги попередньо обговорюватимуться з консультантами.

14 квітня 1918 року О. Цвікевич реалізував перше завдання делегації: українська сторона виконала прохання щодо повідомлення через свій радіотелеграф про проголошення незалежності БНР та ії прагнення розпочати переговорний процес із сусідніми державами щодо визначення лінії кордонів.

Наступного дня УЦР розглянула пропозицію білоруської делегації щодо закупівлі українською стороною дров з попереднім авансуванням 
у 3000000 карб. й доручила Міністерству продовольчих справ провести переговори $з$ державними чи громадськими інституціями Білорусі стосовно закупівлі дров, видавши відповідний аванс [15, с. 280]. Виконувач обов'язків Державного контролера Дмитро Симонів висловив протест проти такої неоформленої торгової операції.

Переговори української комісії та білоруської делегації розпочалися позапланово, а реального часу існування УНР залишалося два тижні. На відміну від запропонованого білоруською делегацією етнографічного принципу у визначенні кордонів, українська сторона наполягала на економічному та географічному. Зрештою, сторони дійшли консенсусу, прийнявши етнографічний принцип з урахуванням взаємних географічних та економічних інтересів. Не було згоди й щодо карти, за якою мали встановлюватися кордони: білоруси пропонували використовувати матеріал академіка Ю. Карського 1917 року і професора С. Рудницького, а українці професора Д. Шефереа від німецького генштабу.

Упродовж 19-22 квітня делегація встигла провести 4 засідання з представниками УНР стосовно остаточного узгодження державних кордонів. Консультанти не брали участі в офіційних засіданнях, але активно долучалися до розгляду проблемних питань під час нарад співробітників делегації. Зокрема, на обговоренні від 20 квітня 1918 року, в якій взяли участь О. Цвікевич, С. Рак-Михайловський, І. Курилович і М. Довнар-Запольський, сумніви в поспішності проведення переговорів без попереднього обговорення позиції з консультантами висловив I. Красковський. Він наполягав на «затягуванні» переговорів, розробленні тактики впливу на запланований переговорний процес УНР і РСФРР із метою примусити Україну обстоювати визнання Росією незалежності Білорусі, визнанні білоруського варіанта окреслення кордонів, без поступок українській стороні. Його принципова позиція грунтувалася на тому, що жодна угода не може бути підписана до оголошення про офіційне визнання Україною незалежності Білорусі. Відтак він пропонував на наступному засіданні за участі українських представників зробити заяву про «неофіційність» переговорів та потребу додаткового узгодження лінії кордону, яка б задовольняла відповідні білоруські кола, а саме: на південних кордонах Мінської і Гродненської губерній. Щодо так званого планованого «захоплення» Україною білоруських земель І.Г. Красковський пропонував висловити «рішучий протест» [28, с. 112]. Його позицію поділяв М.В. ДовнарЗапольський, який вказав на потребу демонстрації білоруською стороною активнішої позиції й наполяганні дотримуватись етнографічного принципу визначення кордонів. За його зауваженням, «уряд Української ради, хоч і висловив симпатію новому державному утворенню, виказав низку коливань і став виявляти імперіалістичні тенденції в сенсі легального за- 
хоплення південних частин Білорусії» [17, с. 558]. С. Рак-Михайловський зі свого боку констатував, що «період романтичних відносин українців до білорусів минув» [21]. М. Довнар-Запольський запропонував новий підхід до вирішення ситуації шляхом з'ясування ставлення до білоруської проблеми Польщі, Німеччини та Росії, вважаючи, що останні більше зацікавлені у зміцненні державних позицій Білорусі, аніж Польщі чи України. Відтак з огляду на велику протяжність кордонів із більшовицькою Росією українцям і полякам Білорусь потрібна як самостійна держава. Однак зміна тактики, підтримана в Мінську, не привела до успіху. За зауваженням М. Довнара-Запольського, білоруська сторона втратила інтерес до переговорів через територіальні претензії УНР та зволікання щодо виконання обіцянки про матеріальну підтримку перед німецьким урядом. Здобутками білоруської місії, яка опиралася на місцеву білоруську раду, він уважав «опротестування захоплення українцями південних повітів Білорусі», «обстоювання права білорусів на самовизначення на тій частині території, де переважали білоруси», «боротьбу проти українізації повітів, обстоювання білоруської школи», «досягнення відправлення в білоруські повіти українських комісарів з числа природних білорусів» [17, с. 558]. Зі складеним М. Довнаром-Запольським «меморіалом», у якому обгрунтовувалися історичні засади державності та економічної незалежності Білорусі, члени офіційної білоруської делегації відвідали посла Німеччини А. Мумма, сподіваючись переконати в політичному (потребі збереження цілісності території БНР і підтримки державного будівництва) та економічному (як імпортера сільськогосподарських товарів та ринку збуту для товарів німецького виробництва) значенні БНР для Німеччини. Проте німецька позиція щодо визнання незалежності БНР залишалася незмінною. А за кілька днів остаточно зупинилися й переговори з УНР через прихід до влади 29 квітня 1918 року гетьмана П.П. Скоропадського.

На відміну від складності й низької результативності переговорів білоруської делегації з українською стороною з політичних питань, в економічній сфері був певний успіх. Зокрема він виявився в досягненні згоди на відкриття Білоруського торгового представництва в Києві. Народний Секретаріат БНР затвердив статут, персональний склад та місце перебування Центральної Білоруської Торгової Палати 24 квітня (в інших документах 25) 1918 року. Мета іiі діяльності визначалася як організація товарообміну з УНР, зокрема закупівель хліба та інших товарів. Місцем розташування Торгової палати було визначено Київ, керівником призначено П. Кречкевського [31, арк. 55-56]. У структурі нового органу виокремлювалося управління в складі голови, заступників, юрисконсульта і двох членів; «технічного апарату» (завідувач, помічники, спеціальні агенти) та членів, якими могли бути лише громадяни БНР (фахівці в га- 
лузі торгівлі, промисловці, науковці), функції консультантів мали право виконувати й не громадяни БНР. На Торгову палату в Києві покладалися завдання підготовки для Народного Секретаріату БНР аналітичної інформації про стан торгівлі та промисловості УНР, збирання даних про білорусько-український товарообмін та інформування зацікавлених сторін, формулювання пропозицій щодо розвитку двосторонніх торговельно-економічних відносин, приймання замовлень на товари масового вжитку та здійснення організаційних заходів щодо виконання цих замовлень, проведення в УНР виставок білоруських товарів. Водночас Торговій палаті надавалися повноваження представництва економічних інтересів БНР в УНР і обмежені консульські функції, пов'язані із захистом інтересів білоруських громадян та утворених ними підприємств, зокрема й в арбітражних судах [31, арк. 197]. Фінансування діяльності Торгової палати передбачалося коштом Народного Секретаріату та відрахуваннями з прибутку від виконання договорів, а кошторис підлягав затвердженню урядом [31, арк. 196].

Білоруська торгова палата з товарообміну на території України (переважно називалася скорочено - Білоруська торгова палата) декларувала намір налагодження товарообміну між УНР та БНР, насамперед товарами масового споживання, й запрошувала до співпраці установи, фірми й приватних осіб. Спершу вона розташувалася в приватному приміщенні Ф. Базаревича на вулиці Троїцькій (нині провулок Рильський) у будинку № 4, кв. 1. Очолив установу М. Довнар-Запольський, який утім не залишав викладацької роботи. Посаду заступника голови Білоруської торговельної палати обійняв Ф. Бурчак - достатньо авторитетна в Києві людина. На той час він мав неабиякий досвід діяльності у Київській міській управі (був заступником Київського міського голови і виконувачем обов'язків міського голови) та лікарської практики, зокрема боротьби з епідемією тифу в Києві. Випускник медичного факультету Київського університету Св. Володимира, Ф. Бурчак розпочав практичну діяльність сільським лікарем Скричанської дільниці Мозирського повіту Мінської губернії [32, арк. 97], 30 вересня 1887 року його було переведено на посаду сільського лікаря Річицької дільниці. Упродовж 10 років він працював у Білорусі, у серпні 1899 року разом із дружиною - дворянкою В. Летецькою та трьома синами приїхав до Києва, де отримав посаду лікаря при Київській духовній семінарії. 3 січня 1904 року його було обрано членом Київської міської управи, очолював відділ у справах місцевого господарства, а від 1908 року виконував обов'язки заступника Київського міського голови, у червні 1915 року став гласним Київської міської думи, через рік отримав звання статського радника, у 1916 році очолив Київську міську управу. Ф. Бурчак був членом опікунської ради Київського Першого комерційного училища, 
головою опікунської ради Київської лісової гімназії, головою міської училищної комісії, членом київського комітету Всеросійського союзу міст. У січні 1917 року очолив Особливий комітет по завідуванню в Києві госпіталем № 1, де здобував хірургічну практику П. Тремпович, та Києво-Подільський Хрестовоздвиженський лазарет, за «отлично-усердную службу и труды понесенные во время военных действий» був нагороджений орденом Св. Рівноапостольного кн. Володимира 4-го ступеня [32, арк. 97], орденами Св. Станіслава 2 і 3-го ступенів, Св. Анни 2-го ступеня.

Обов'язки юрисконсульта та члена правління палати виконував Григорій Федорович Базаревич, членом правління був Іван Васильович Курилович, секретарем - підпоручик Ричард Францевич Хергет, який опинився в Києві в травні 1916 року після поранення під час боїв Першої світової війни у районі Барановичів на Північно-Західному фронті. Білоруська торгова палата пропонувала «вигідні умови» білоруським виробникам щодо представництва їхніх інтересів для продажу в Україні товарів і планувала «виклопотати право» на вивіз до Білорусі продуктів продовольства [31, арк. 56]. Однак можливостей для розгортання торговельно-економічної співпраці БНР із УНР за посередництва Білоруської торгової палати вже не було.

У цей час керівник Білоруської делегації у справі переговорів УНР і БНР О. Цвікевич, дізнавшись про призначення А. Квасницького консулом Української Держави в Мінську, довів до відома Народного Секретаріату БНР рішення делегації від 11 травня 1918 року про нагальну потребу призначення консула БНР в Україні. Як найвідповідніша кандидатура на цю посаду розглядався Павло Вікторович Тремпович, який долучився до роботи делегації як консультант [31, спр. 10, арк. 111].

Він народився 28 травня (за іншими даними - 1 червня) 1888 року у родині залізничника у Пскові, де сім'я Тремповичів опинилася через непримириму до несправедливості вдачу діда. За участь у національно-визвольному повстанні 1863-1864 pр. його з родиною було вислано з Вільно до Вітебська (де й народився батько Павла), а невдовзі - за участь у демонстрації проти відібрання у католиків костелу - за межі Північно-Західного краю, у Псков [33]. Виховували Павла в любові до національних звичаїв спокійного й працьовитого білоруського народу. В дідовій оселі постійно знаходили притулок селяни-втікачі, які шукали кращої долі.

Середню освіту П. Тремпович отримав у Псковському Сергіївському реальному училищі, яке закінчив 1 червня 1907 року [34, арк. 8]. Потому з 16 серпня 1907 до 31 липня 1908 року навчався в додатковому класі цього училища. Його інтереси тяжіли більше до гуманітарних предметів: відмінні оцінки всвідоцтві про закінчення навчання були зЗакону Божого, німецької і французької мов, історії та природознавства; арифметика, алгебра, тригонометрія, фізика й малювання оцінювалися на «задовільно» [34, арк. 14]. 
3 юнацького віку П. Тремпович брав участь у революційних гуртках, а перед закінченням навчання вступив до партії соціалістів-революціонерів. Прагнення бути «в гущі білоруського народу» й вести там культурну національну діяльність зумовило його шлях в медицину. Відтак 1908 року він вступив до Психоневрологічного інституту при Петербурзькому університеті. Але через арешти за участь у політичних демонстраціях після двох років навчання був змушений емігрувати до Німеччини. Спроба продовжити опанування наук на медичному факультеті Баварського університету без досконалого знання мови й засобів для існування завершилася переведенням до Київського університету Св. Володимира. У вересні 1910 року він став студентом історико-філологічного факультету університету, а вже 15 вересня подав заяву на переведення його на медичний факультет. 22 вересня 1910 року П. Тремпович отримав можливість здобувати медичну кваліфікацію [34, арк. 11]. Та вже у вересні 1911 року він попросив перевести його на юридичний факультет, мотивуючи матеріальними труднощами під час навчання.

У січні 1913 року студент одружився з 22-річною студенткою Вищих жіночих курсів О. Горбенко. 3 початком Першої світової війни юнак опинився на Південно-Західному фронті. Упродовж серпня 1914 - грудня 1916 років працював молодшим ординатором Київського госпіталю, набуваючи практичного досвіду в хірургії. Державні іспити перед Медичною імператорською комісією при Київському університеті Св. Володимира йому вдалося скласти лише в травні 1917 року. Найвища оцінка в його атестаті, виданому 30 травня 1917 року, була з предмета «оперативна хірургія з топографічною анатомією» [34, арк. 181]. Уже з дипломом молодий спеціаліст П. Тремпович отримав посаду в хірургічному відділі Київського залізничного госпіталю, згодом - 1-го госпіталю Всеросійського земського союзу, який очолював його легендарний земляк Ф. Бурчак. Тут П. Тремпович пройшов шлях від ординатора до головного лікаря. Лютневу революцію він зустрів у Києві: одразу поновив контакти з білоруськими організаціями, проводив агітаційну й просвітницьку працю. У квітні 1918 року вирушив до Мінська, де увійшов до складу Народного Секретаріату БНР.

До прибуття в Київ генерального консула з дипломатичними повноваженнями білоруська делегація вдавалася до непродуктивних кроків, зокрема: у травні 1918 року іiі керівник офіційно звернувся до Х. Раковського, який очолював з російського боку переговорний процес із гетьманським урядом у Києві, з проханням довести до відома більшовицького уряду інформацію про утворення БНР і бажання їі Секретаріату укласти угоду з Росією про державні кордони $[17,558]$. Ишлося також про підтримку російською делегацією білоруської в суперечках щодо державного кордону. 
Але вже на початку червня 1918 року завдання досягти через німецького посла в Києві визнання Німеччиною незалежності Білорусі й уряду БНР отримав П. Тремпович. Нелегально діставшись до Києва, він долучився до складу білоруської делегації у справі переговорів УНР і БНР. Газета «ББлорусское эхо» від 10 червня повідомила про призначення «члена Білоруської торговельної палати» лікаря П. Тремповича консулом БНР у Києві, зауваживши, що досі «обов'язки консула» виконувала Білоруська торговельна палата [35]. Жодних офіційних підстав для такої заяви не було, однак з погляду налагодження торговельних відносин між БНР і Українською державою та контактів між білоруськими громадянами можна було припустити таке висловлювання.

Проте рішення про делегування П. Тремповича до Києва як представника уряду БНР із правами генерального консула в Києві та дипломатичного представника при МЗС Української Держави на звернення О. Цвікевича Народний Секретаріат БНР ухвалив лише 15 червня 1918 року [31, спр. 10, арк. 118]. Генеральне консульство БНР у Києві, офіційно засноване з 16 червня 1918 р., відкрило Павлу Тремповичу зокрема й можливості щодо виконання завдання, з яким він прибув до Києва. БНР прагнула якнайшвидше встановити з Українською Державою економічні відносини не менше, ніж політичні. Головним завданням консула було налагодження товарообміну між українськими і білоруськими виробниками через посередництво Білоруської торговельної палати в Києві. Згідно з постановою Народного Секретаріату БНР від 2 липня 1918 р. П. Тремпович із очільником торговельної палати М. Довнаром-Запольським мав розробити і укласти угоду щодо умов організації білорусько-українського товарообміну. Білоруською стороною передбачалося, що така попередня домовленість діятиме до моменту підписання сталого торговельного договору. Конкретні пропозиції щодо поставляння дров, сірників, скляних виробів та запити на отримання мила, махорки, цвяхів, солі, сільськогосподарського приладдя надійшли 12 липня 1918 року. Планувалося укласти торгові угоди на суму 10000000 рублів на рік. Однак українська сторона не поспішала з позитивною відповіддю, визнаючи товарообмін з БНР бажаним у тій мірі, яка випливала з тогочасних економічних відносин та зовнішньополітичної ситуації і залежності від окупаційної влади. Керівник Білоруської торгової палати М.В. Довнар-Запольський констатував, що «генеральної угоди палаті укласти не вдалося, хоч кілька сепаратних угод із українським міністерством торгівлі і промисловості було укладено» [17, с. 565]. Палаті вдалося отримати офіційний дозвіл на відправку транспортів 3 цукром і хлібом в обмін на ліс. Проте сприянням «білоруських більшовицьких організацій, що працювали в Києві», відправлялися й товари без офіційного дозволу [17, с. 565]. 
Народний Секретаріат БНР 21 липня 1918 року розширив повноваження свого представника, надавши йому права надзвичайного посланника в уряді Всевеликого Війська Донського з метою встановлення економічних і дружніх зв'язків. Перебування П. Тремповича в Києві передбачалося використати й для встановлення контактів із кубанською делегацією (на чолі з головою законодавчої ради М. Рябоволом), яка з кінця травня перебувала в переговорному процесі з Українською Державою, шукаючи підтримки в боротьбі з більшовиками. Відтак вірчі грамоти, що визначали зміст його повноважень в УНР та Всевеликому Війську Донському, були датовані 22 липня 1918 року. Генеральному консулові надавалося право вести всі переговори відповідно до звання і становища, укладати угоди 3 обміну товарами і продуктами промисловості між БНР і УНР, БНР і Всевеликим Військом Донським, встановлювати залізничні зносини, поштовий і телеграфний зв'язок між УНР і БНР. Крім того, він та підлеглі йому співробітники мали виконувати ще одну ключову консульську функцію захищати права та інтереси білоруських громадян на територіях України та Всевеликого Війська Донського. Із цією метою П. Тремповичу делегувалося право зносин від імені білоруського народу відповідно до норм міжнародного законодавства з усіма органами влади нових державних утворень [31, спр. 10, арк. 118].

Невідкладно вирішило вище білоруське керівництво і «технічні питання». Народний Секретаріат БНР 22 липня 1918 року затвердив штатний розпис консульства в Києві та авансував на організацію його роботи 21 тис. рублів на три місяці з умовою оплати оренди приміщення на рік. Штат консульства мав 5 посад: генерального консула (оклад 1200 руб.), управителя канцелярії (750 руб.), паспортиста (350 руб.), друкарки (350 руб.), служителя (200 руб.) [31, спр. 10, арк. 105]. Планувалося, що генеральне консульство зможе отримувати прибуток не менше 250 тис. рублів на рік і поповнювати тим самим казну БНР [31, спр. 10, арк. 104]. Додатково виділялося 5000 рублів на «справу пропаганди» - утримання газети «Беларускае Эхо». Генеральному консулові доручалося скласти акти і пронумерувати платні бланки консульства разом із керівниками білоруських урядових організацій у Києві та надіслати оригінали актів у Мінськ.

Водночас він отримав доручення досягти домовленості з українським урядом про тимчасову грошову позику розміром до 5 млн крб на «умовах йому указаних» та отримати ці гроші для передачі Народному Секретаріату БНР [31, спр. 10, арк. 122]. До вступу на посаду генерального консула виконання його обов’язків покладалося на О. Модзалевського [31, спр. 10, арк. 78].

Білоруське генеральне консульство розміщувалося у Києві в будинку № 42 на вулиці Фундуклеївській. Його робота розпочалася з організації реєстрації білоруських громадян. За підрахунками П. Тремповича, на терито- 
рії України проживало близько 100000 білорусів [31, спр. 10, арк. 104]. За видавання та візування паспортів консул планував отримати 200000 рублів консульських зборів. Однак одержати екзекватуру білоруському посланнику швидко не вдалося. 3 політичних міркувань МЗС Української Держави зволікало з офіційним визнанням білоруського представника. На запит німецького посольства від 12 вересня щодо наявності білоруського консула в Києві, зовнішньополітичне відомство констатувало: «в Україні нема жодних представників Білоруської республіки: ні дипломатичних, ні консульських. Якби такі особи з'явилися, то МЗС буде вважати їх за фактичних, а не юридичних представників» [36, арк. 9].

Прохання до МЗС Української Держави про «призупинення» консульських повноважень та повернення «вірчої грамоти» 3 жовтня 1918 року подав білоруський консул, мотивуючи отриманням нового призначення від Уряду БНР. Як особа, що не мала фахової підготовки й належного досвіду консульської служби та розумілася на особливостях ведення дипломатичного протоколу і процедурах призначення консулів, П. Тремпович виявив особисту ініціативу попри процедурні вимоги. Поки що в архівах не виявлено матеріалів про причини його відмови від виконання консульських обов'язків. Не видається переконливою версія про його звільнення через відмову прийняти українське громадянство.

Очевидно, скориставшись другою грамотою, яка уповноважувала його на встановлення контактів із Доном, П. Тремпович виїхав у Ростов-на-Дону і Новочеркаськ, де зайнявся приватною лікарською практикою і допомогою білорусам-біженцям [33]. До призначення нового консула управляв справами Олександр Йосипович Модзолевський [36, арк. 8].

У жовтні 1918 року до Києва прибула ще одна делегація БНР, очолювана А. Луцкевичем. До їі складу увійшли: Федір Бурчак, Олександр Капустинський, Язеп Варонка, Антон Аусянік та Лявон Лєущченко. Делегація двічі зустрілася з міністром закордонних справ Д. Дорошенком, а 9 жовтня - з гетьманом П. Скоропадським, який на словах підтвердив визнання de facto незалежності Білорусі своїм урядом та обіцяв пришвидшити рішення про формальне визнання незалежності БНР Радою Міністрів Української Держави [28, с. 291]. Дуже важливим та непорівнянним наслідком білорусько-української співпраці була позика, надана Україною, яка уможливила не лише фінансування виїздів делегації БНР на чолі 3 А. Луцкевичем до Парижа під час мирної конференції, а й подальшу роботу, зокрема і Дипломатичної місії БНР в Берліні.

До офіційного призначення генерального консула БНР в Українській Державі 30 жовтня 1918 р. Народний Секретаріат БНР надав повноваження тимчасового керівника Білоруського генерального консульства в Києві «з усіма присвоєними йому і витікаючими 3 його становища правами і 
обов’язками» [37, арк. 129] члену правління Білоруської торговельної палати Г. Базаревичу з проханням визнати права білоруського представника і сприяти у виконанні доручених йому обов'язків.

Однак новий представник також не зміг прискорити налагодження білорусько-українського товарообміну через неоднозначне ставлення до діяльності Білоруської торгово-промислової палати. «Київська білоруська торговельна палата в ії сучасному складі, яка взагалі складається з осіб досі невідомих в Білоруському національно-громадянському русі не дає певности, що ії діяльність з боку політичного може відповідати інтересам України, - вважали в міністерстві. - Навпаки в МЗС маються відомості про шкодливі наслідки діяльності палати і тому до реорганізації їі зав'язання торговельних зносин з нею з боку політичного не бажано і не корисно» [36, арк. 21]. Таку офіційну відповідь МЗС Української Держави надало Мінську 25 листопада 1918 року.

Ситуацію мав змінити приїзд до Києва 28 листопада 1918 року О. Цвікевича. Йому делегувалося право як керівникові Особливої торгово-економічної комісії - «вищого торгово-економічного органу Білоруського Уряду в Україні» [36, арк. 35] - проведення переговорів з Міністерством торгу і промисловості щодо товарообміну з метою підписання договору на засадах взаємності. На правах членів делегації в переговорах мали взяти участь М. Довнар-Запольський та І. Красковський.

Письмовий запит О. Цвікевича щодо принципової згоди на підписання угоди був підтверджений МЗС Української Держави 9 грудня 1918 року як «бажаність» «заключення торгово-економічного договору з урядом БНР» [36, арк. 36]. Текст договору мав положення про права громадян, умови організації торгівлі та судноплавства, транзиту товарів, створення українсько-білоруської змішаної комісії. У частині організації консульських зносин передбачалося право кожної сторони призначати генеральних консулів, консульських та торговельних агентів у всі міста та принципу взаємності щодо надання пільгових прав» [36, арк. 41]. Договір мав набути чинності до ратифікації, одразу після підписання, однак цього не відбулося.

Останні контакти офіційних білоруських представників з урядом УНР зафіксовані в жовтні 1920 року. Голова Ради БНР П. Кречевський звернувся до С. Петлюри «щодо нав'язання тісного порозуміння між Білоруссю і Україною». Головний Отаман і Міністр закордонних справ УНР А. Ніковський підтвердили готовність порозумітися і «солідарно нести політику в напрямі забезпечення Ваших і наших державних здобутків» [38], та висловили готовність прийняти в ставці в м. Тарнові уповноваженого міністра О. Цвікевича для обговорення важливих для обох країн питань. Проте і в цій ситуації офіційне визнання не зумовило позитивного результату. 
Отже, упродовж 1917-1920 рр. були неодноразові спроби встановити офіційні міждержавні відносини між новоутвореними після розпаду Російської імперії державами Білоруською Народною Республікою та Українською Народною Республікою, а згодом і Українською Державою. Українська сторона демонструвала підтримку у боротьбі за незалежність Білорусі. Зі свого боку білоруська сторона розраховувала на політичну, фінансову та економічну допомогу від України. Скеровані до Києва офіційні представництва були орієнтовані на отримання такої допомоги, водночас маючи завдання надавати сприяння білоруським громадянам, які перебували на території України. Головною причиною неузгодженості позицій під час переговорів українських і білоруських представників стали рішення Брестських мирних переговорів та невизнання незалежності Білорусі адміністрацією в Києві, яка залежала від німецької окупаційної влади. Тому результати діяльності Білоруської торгової палати були завдяки швидше неофіційним, ніж офіційним відносинам. Помітний внесок у розвиток українсько-білоруських відносин того часу зробили О. Цвікевич, П. Тремпович, М. Довнар-Запольський, Ф. Базаревич. Однак романтичні сподівання на всебічну підтримку українськими сябрами нівелювалися реаліями життя та внутрішньої політики БНР.

1. Шульгин Олександр. Fatum історії (спроба історико-психологічного аналізу) // Політика (Державне будівництво України і міжнародні справи): статті, документи, промови. К.: Друкар, 1918. - С. 15.

2. Кукса Александр. Украинская дипломатия начиналась в Беларуси // Беларусская думка, 2012. - № 11. - C. 68-74.

3. Лебедзева В. Дыпламатычная місія БНР у перамовах з Украінай (1918 г.) // Białoruskie Zeszyty Historyczne. Białystok, 2001. - T 15. - C. 97-108.

4. Лебедзева В. Тэрытарыяльнае пытанне на беларуска-ўкраінскіх перамовах 1918 г.: факталагічны і крыніцазнаўчы аспекты // Архівознавство. Археографія. Джерелознавство: міжвід. зб. наук. пр. Київ, 2000. Вип. 2: Архівознавчі читання. - С. 104-113.

5. Зубко О., Трус М. Білоруський слід українській дипломатії: (крізь призму життя Івана Красковського) // Київ. старовина, 2008. - № 4. - С. 92-101.

6. Зубко О. Іван Красковський - голова української дипломатичної місії УНР на Кавказі (1919-1920рр.) / О. Зубко // Проблеми історії та історіографії України: прогр. і матеріали наук.-практ. конф. - К., 2011. C. $30-32$.

7. Матвієнко В. Державно-політичні відносини та налагодження економічного співробітництва Української держави з Білоруською Народною Республікою // Пам'ять століть, 2003. - № 1. - C. 47-58.

8. Матвієнко В.М. Проблеми формування українсько-білоруських відносин: історичний досвід // Дипломатична академія України: наук. вісн. К., 2001. - Вип. 5: Українська зовнішня політика та дипломатія: десять років незалежності. - С. 297-305.

9. Матвієнко В.М. Розвиток українсько-білоруських відносин за доби Директорії // Вісн. Акад. праці і соц. відносин Федер. профспілок України, 2002. - № 2, ч. 2. - С. 39-41.

10. Матяш І. Українська консульська служба 1917-1923 рр. як державний інститут: становлення, функціонування, персоналії. - Київ: Ін-т історії України НАН України. - 482 с.

11. Матяш І. Внесок білоруса Івана Красковського у формування української дипломатії (1918-1921рр.) // Україна-Європа-Світ. Міжнародний збірник наукових праць. Серія: Історія, міжнародні відносини / гол. ред. Л.М. Алексієвець. - Вип. 19. - Тернопіль: Вид-во ТНПУ ім. В. Гнатюка, 2017. - С. 314-329.

12. Панасюк О.П. Білоруська Народна Республікау 1918 - 1919 рр.: внутрішня і зовнішня політика: дис. ... канд. іст. наук. - Луцьк, 2016. - С. 106-112. 
13. Міхалюк Д. Дипломатичні зносини Білоруської Народної Республіки та Української Народної Республіки і Гетьманату у світлі документів (березень-грудень 1918 р.) // Студії з архів. справи та документознавства. К., 2004. - Т. 12. - С. 107-114.

14. Міхалюк Д. Беларуская Народная Республіка 1918 - 1920 гг:. ля вытокау беласкайдзяржаунасцы / Дарота Мыхалюк; навук. рэд. Станіслау Рудовіч; переклад з поляскай мовы Алесь Пілецкі. - Смаленск: Інбелкульт, 2015. -496 c.

15. Українська Центральна Рада: докум. і матеріали: У 2 т. Т. 2 / упоряд. В. Верстюк та ін. - К.,1997. - 424 с.

16. Центральний державний архів вищих органів влади та управління України (ЦДАВО України). Ф. 2592. Оп. 4. Спр. 15. Арк. 48.

17. Довнар-Запольский М.В. История Беларуссии. - Мн.: Беларусь, 2003. - С. 538.

18. Канчер Е.С. Из истории общественных, национальных и революционных движений белорусов // Неман, 1993. - No 1. - C. 138.

19. Рудовіч С. Час выбару. Праблема самавызначення Беларусі у 1917 годзе. - Мінск: «Тэхналогія», 2001. - С. 201.

20. Вабішчэвіч Аляксандр. Аляксандр Цвікевіч (1883-1937) // Bialoruskie Zeszyty Historychne. - 2000. - № 14.

[Електронний ресурс]. - Режим доступу до ресурсу: http://kamunikat.fontel.net/www/czasopisy/bzh/14/14biogr_ vabiszczevicz.htm

21. Пашкевіч А. Сымон Рак-Міхайлоўскі: старонкі жыцця і дзейнасці // Куфэрак Віленшчыны. 2007. - № 1 (12). C. $4-30$.

22.ЦДАВО України. Ф. 3696.0п. 1. Спр. 32. Арк. 10.

23. Лєбєдєва В. Витоки білорусько-українських відносин (весна 1918 р.) // Україна дипломатична: науковий щорічник - К., 2016. - Вип. 17. - С. 642.

24. Полонська-Василенко Н. Спогади / упор., вступ. ст. й іменний покажчик В. Шевчука. - Київ: Видавн. дім «Києво-Могилянська Академія», - 2011. - С. 296.

25. Белорусское слово. - №1. 1918, 1 (19) апреля. - С. 1.

26. Лебедева В.М., Скалабан В.В., Шумейко М.Ф. Довнар-Запольський и его наследие // Довнар-Запольский М.В. История Беларуссии. - Мн.: Беларусь, 2003. - С. 7.

27. ЦДАВО України. Ф. 2592. Оп. 1. Спр. 62. Арк. 2.

28. Архівы Беларускай Народнай Реслублікі/Рэд. С. Шупа. Т. 1. Вільня-нью-Ёрк-Менк -Прага, 1998. - Т. 1, кн. 1.

29. ЦДАВО України, ф. 1064, оп. 1, спр. 4, арк. 67-68.

30. Історія української дипломатії: перші кроки на міжнародній арені (1917-1924рр.): документи і матеріали / Держкомархів України, Укр. НДІ архів. справи та документознавства; [авт. передм., упоряд.: І.Б. Матяш та ін.; редкол.: К.І. Грищенко (голова) та ін.]. - К.: Вид-во гуманіт. л-ри, 2010. - 592 с.: табл.

31. Національний архів Білорусі (НАРБ). Ф. 325. Оп. 1. Спр. 166. Арк. 55-56.

32. Державний архів м. Києва, ф. 163, оп. 34, спр. 92, арк. 97.

33. Васілеўская Нона. Жыцьцёвы шлях Паўла Трамповіча // Spadcyna. - 1998. - № 2.

34. Державний архів м. Києва, ф. 16, оп. 465, спр. 90435, арк. 8.

35. ББлорусское эхо. 1918, 10 июня (28 мая). №3. С. 4.

36. ЦДАВО України. Ф. 3766. Оп. 1. Спр. 139. Арк. 9.

37. ЦДАВО України. Ф. 3766. Оп. 1. Спр. 199. Арк. 29.

38. ЦДАВО України. Ф. 3696. Оп. 2. Спр. 418. Арк. 1, 2. 
Iryna MATIASH,

Doctor of Historical Sciences, Professor, Senior Researcher at the Department of History of International Relations and Foreign Policy of Ukraine of the Institute of History of Ukraine of NAS of Ukraine, Head of the Scientific Society of History of Diplomacy and International Relations

\section{FIRST BELARUSIAN FOREIGN MISSIONS IN UKRAINE (1918): attempt to establish diplomatic relations between the UPR and the BPR (romance of hope and reality of being)}

Abstract. The article highlights attempts to establish official intergovernmental relations between the Belarusian People's Republic and the Ukrainian People's Republic in 19171920. The author stresses that the first official contacts had already been started before the proclamation of the independence of the BPR. Relying upon archival information from the funds of the Ukrainian and Belarusian archival institutions, the activities of the Belarusian foreign missions in the UPR and the Ukrainian State are highlighted. Accomplishments of the Ukrainian, Belarusian and Polish historiography regarding the study of the history of interstate relations between the UPR and BPR are considered. The paper analyses the position of Belarusian representatives in the negotiation process with the Ukrainian side. It is specified that the Belarusian delegation having the right to deliberative vote included prominent Belarusians, who resided in Kyiv: M. Dovnar-Zapolskyi, I. Kraskovskyi, F. Burchak. Attempts to gain recognition of the BPR by Ukraine are studied. Special attention is paid to the role of the representatives of the BPR (F. Burchak, A. Tsvikevych, S. Rak-Mykhailovskyi, P. Trempovych), the undisclosed facts about their life paths are revealed.

Keywords: BPR, Belarusian foreign missions in Ukraine, Aleksiuk, Trempovych, Tsvikevych, Dovnar-Zapolskyi, Belarusian Chamber of Commerce. 